\title{
Atmospheric PM2.5 and Its Elemental Composition from near Source and Receptor Sites during Open Burning Season in Chiang Mai, Thailand
}

\author{
Chanakarn Khamkaew, Somporn Chantara, and Wan Wiriya
}

\begin{abstract}
Open burning is an important source of atmospheric particulate matter (PM) emissions in the South East Asian Region. PM2.5 samples were collected in dry season (March 2013) at two sampling locations in Chiang Mai Province, Thailand. Doi Ang Khang (DAK) site is located uphill near the Myanmar border representing a near source site and Chiang Mai University (CMU) is located downhill in the city of Chiang Mai representing a receptor. The samples were collected by mini volume air samplers on a daily basis ( 24 hours) and analyzed for elemental composition. It was found that the average PM2.5 concentration at $\mathrm{CMU}\left(\mathbf{7 4 . 5} \pm 43.5 \mu \mathrm{g} \mathrm{m}^{-3}\right)$ was higher than that at DAK $\left(59.1 \pm 44.1 \mu \mathrm{g} \mathrm{m}^{-3}\right)$. However, they were well correlated $(r=0.780)$ and not significantly different $(p>0.05)$. The major elements found in the PM2.5 samples collected from both sites were $\mathrm{K}, \mathrm{Mg}, \mathrm{Al}$ and $\mathrm{Fe}$. The element with the highest mass content was $K\left(2.06 \mu \mathrm{g} \mathrm{m}^{-3}\right.$ at DAK and $2.23 \mu \mathrm{g} \mathrm{m}^{-3}$ at $\left.\mathrm{CMU}\right)$. Therefore, it can be revealed that biomass burning was a major source of PM2.5 collected at both sites, $K$ is known as a biomass burning tracer. Concentrations of PM2.5 and $K$ at both sites were not much different. This is probably due to large areas of open burning in the upper part of Northern Thailand and in neighboring countries causing haze that covered the whole area. Although there was no significant difference of air pollutants at both sites, correlation between PM2.5 and $K$ was higher at the near source site than the receptor site, supporting that $K$ was emitted from biomass burning. Backward trajectory was performed to identify air mass movement to the sampling sites. The major air mass (45\%) to DAK was from a western direction, while the air movement $(52 \%)$ to $\mathrm{CMU}$ was from a southwest direction.
\end{abstract}

Index Terms-PM2.5, biomass burning, elemental composition, air pollution.

\section{INTRODUCTION}

Air pollution is one of the most important environmental issues which is still yet to be solved. Previous studies show that the biomass burning has impacts on the atmosphere and effects on human health [1], [2]. The main contribution of air pollutants in upper Northern Thailand is biomass burning, including forest fires and crop residues [3], [4]. Moreover, variation of burning materials, topography, burning type and weather result in different chemical composition and size

Manuscript received May 29, 2015; revised August 4, 2015

C. Khamkaew is with the Environmental Science Program, Faculty of Science, Chiang Mai university, Chiang Mai, 50200, Thailand (e-mail: chanakarn53@gmail.com).

S. Chantara and W. Wiriya are with the Environmental Chemistry Research Laboratory (ECRL), Chemistry Department and the Environmental Science Program, Faculty of Science, Chiang Mai university, Chiang Mai, 50200, Thailand (e-mail: somporn.chantara@cmu.ac.th, wanwiriya484@hotmail.com). distribution of particles emitted from biomass burning. Anthropogenic activities including ever increasing vehicle emission, as well as biomass burning are the main contributions of air pollutants in this area. The emission source of PM in Chiang Mai city was studied. The results obtained from this emission inventory with regards to PM10 reveal that PM originates at $97 \%$ from area sources and $2.5 \%$ from mobile sources [5]. The geographical features of the city located in the intermountain basin together with the atmospheric conditions involving temperature inversion in the lower atmosphere in the dry season, are reasons for the air pollutants substantial accumulation. About $80 \%$ of landuse pattern in Chiang Mai Province is forest area, while paddy field and field crop occupy only $5.5 \%$ and $4.5 \%$, respectively. About 700 tons of total PM were emitted from forest fires (89\%), 5.4\% from solid waste burning and $2.3 \%$ from agriculture residue field burning [5]. Moreover, overlaying of the daily hotspot and land use maps of the Northern Thailand was done using ArcView GIS for March 9-15, 2007 (period of the highest numbers of daily hotspots) and indicated that $80 \%$ were detected in the forest areas and $20 \%$ were in the agriculture areas (mixed swidden cultivation, paddy field, and corn plantation) [4]. In addition, the ratio of PM2.5/PM10 during biomass burning period was found to range from 0.71 to 0.93 [1], [3]. It means that PM2.5 is a major part of particulate matter emitted from biomass burning, constituting more than half of the mass. PM2.5 has been found to cause health problems [6]. Due to the large surface area of PM2.5, toxins, including PAHs and heavy metals are absorbed onto the surface. It can trigger or exacerbate conditions, such as asthma, emphysema, bronchitis, silicosis and lung cancer [7]. This work was carried out in the framework of the Seven South-East Asian Studies (7-SEAS) project, which was focused on investigating the effect of biomass burning. 7-SEAS project was established to perform interdisciplinary research in aerosol-meteorology and climate interaction in the SE Asian region [8]. One of the study areas in Thailand is Doi Ang Khang (DAK), Chiang Mai Province. A joint field study of sampling PM2.5 concentration at DAK in 2013 was cooperated. The purpose of this study is to determine and compare atmospheric PM2.5 and PM2.5-bound elemental composition collected from near source and receptor sites during the open burning season.

\section{METHODOLOGY}

\section{A. Sampling Site}

The 24 hours PM2.5 samples were collected from ambient 
air at two sampling sites in Chiang Mai Province, Thailand. The first sampling site is Doi Ang Khang (DAK), in the Fang District $\left(19^{\circ} 55^{\prime} 57.61^{\prime \prime} \mathrm{N}, 9^{\circ} 2^{\prime} 42.61^{\prime \prime} \mathrm{E}\right)$, which is a sub-meteorological station located near Myanmar border. Its altitude is $1534 \mathrm{~m}$ above sea level and it is about $130 \mathrm{~km}$ north of Chiang Mai City. The DAK site is situated on top of the mountain surrounded by forest and some agricultural fields. In dry season open burning is quite intensive. Therefore, it was selected to represent a near source of biomass burning. The second site is located at Chiang Mai University (CMU) $\left(18^{\circ} 48^{\prime} 5.40^{\prime \prime} \mathrm{N}, 98^{\circ} 57^{\prime} 12.18^{\prime \prime} \mathrm{E}\right)$. This site is in the city of Chiang Mai representing the receptor site. To avoid effect from traffic, the sampling was set at the rooftop of a nine-storey building. The altitude of the CMU site is $373 \mathrm{~m}$ above sea level. The detail of the sampling site is shown in Fig. 1. PM2.5 concentrations at CMU site were compared with the values obtained from an automatic active sampler (Taper Element Oscillation Microbalance; TEOM) at the air quality monitoring (AQM) station belonged to the Pollution Control Department (PCD) located at Yupparaj Wittayalai School (YP). The data at DAK was compared with the TEOM belonged to the National Central University (NCU), Taiwan measured at the same site, which was under Seven South-East Asian Studies (7-SEAS) project.

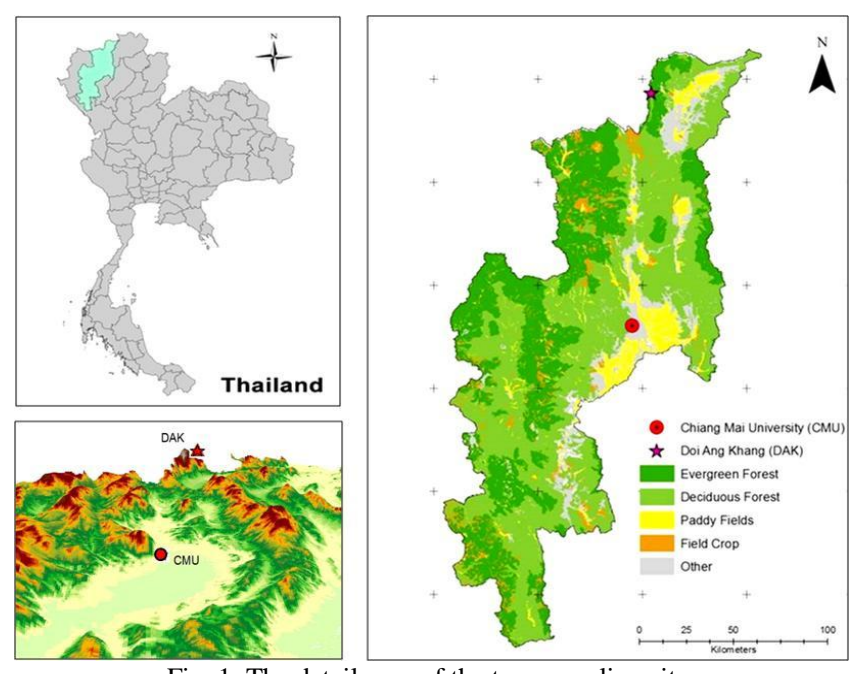

Fig. 1. The detail map of the two sampling site.

\section{B. Sample Collection}

The PM2.5 samples were collected in the dry season (1-31 March 2013). The samples were collected on pure quartz fiber filter (Whatman's, UK, Ø $47 \mathrm{~mm}$.) by using a mini volume air sampler (MiniVol, Airmetrics, USA) at a flow rate of $5 \mathrm{~L} / \mathrm{min}$ with sampling intervals of 24 hours. Samples from 2 sampling sites were collected at about the same time. The filters were stored in desiccators before and after sampling for 24 hours prior to being weighed using the microbalance (Toledo, Switzerland). The filters were weighed three times under the controlled temperature $\left(27 \pm 2{ }^{\circ} \mathrm{C}\right)$ and relative humidity $(41 \pm 5 \%)$ conditions. Subsequently, filters were kept in a freezer until extraction.

\section{Air Mass Movement}

The 24 hours backward trajectory in March 2013 was performed by using the Hybrid Single-Particle Lagrangian Integrated Trajectory (HYSPLIT) model and the Air
Resources Laboratory [9] to evaluate sources of air mass movement to CMU and DAK sampling sites. The starting point altitudes were $373 \mathrm{~m}$ (CMU) and $1534 \mathrm{~m}$ (DAK) above sea level (ASL) with starting time at 00 UTC.

\section{Analysis of PM2.5 Elemental Composition}

The PM2.5 sample filters were extracted with $4 \mathrm{~mL}$ of aqua regia $\left(\mathrm{HCl}+\mathrm{HNO}_{3} ; 3: 1 \mathrm{v} / \mathrm{v}\right)$ by Double Layer Teflon Digestion Bomb at the temperature of $140{ }^{\circ} \mathrm{C}$ for 4 hours [10]. After extraction, the volume was adjusted with $2 \% \mathrm{HNO}_{3}$ to $25 \mathrm{~mL}$ in a volumetric flask. Extracted solutions were filtered with $0.45 \mu \mathrm{m}$ nylon membrane and stored at $4{ }^{\circ} \mathrm{C}$ prior to analysis. Twelve elements ( $\mathrm{Al}, \mathrm{Cd}, \mathrm{Cr}, \mathrm{Cu}, \mathrm{Fe}, \mathrm{K}, \mathrm{Mg}, \mathrm{Mn}, \mathrm{Ni}$, $\mathrm{Pb}, \mathrm{Sb}$ and $\mathrm{V}$ ) were analyzed by using ICP-OES (Optima 3000, Perkin Elmer, Germany). The sample solutions were measured in triplicates, while quality control was done by using a mixed standard solution $(1.25 \mathrm{ppm})$ for comparison at every 15-20 sample injections. Blank samples $(n=7)$ of PM2.5 were also extracted and analyzed by using the same method as the other. A median value was used for background subtraction from each sample.

\section{E. Data Quality Control}

The accuracy of the analysis and extraction condition was checked by $100 \mathrm{~g}$ of Standard Reference Materials (SRMs) urban dust 1648a (National Institute of Standard \& Technology; NIST). Five sets of about $100 \mathrm{mg}$ were extracted using the same method as the samples. Moreover, the spiking method of mixed elements standard solution $\left(0.5 \mu \mathrm{g} \mathrm{mL}{ }^{-1}\right)$ was also observed. Recoveries (83-113\%) of elements $(\mathrm{Cd}$, $\mathrm{Cu}, \mathrm{Fe}, \mathrm{Mg}, \mathrm{Mn}, \mathrm{Ni}, \mathrm{Pb}, \mathrm{Sb}$ and $\mathrm{V}$ ) were compared with the certified values of the SRMs urban dust. The rest of the elements ( $\mathrm{Al}, \mathrm{Cr}, \mathrm{Cu}, \mathrm{Fe}, \mathrm{K}, \mathrm{Mg}, \mathrm{Mn}, \mathrm{Ni}, \mathrm{Pb}$, and $\mathrm{V}$ ) were spiked, and their recoveries were $78-111 \%$. Precision of the method was obtained from 5 injections of $1.25 \mu \mathrm{g} \mathrm{mL}^{-1}$ mixed standard solution into ICP-OES. Good precision was obtained both for repeatability (0.6-7.8\%RSD) and reproducibility (3.1-11.9\%RSD).

\section{RESUlTS AND DISCUSSION}

\section{A. PM2.5 Concentrations}

The PM2.5 concentrations are presented in Table I. The maximum PM2.5 concentration $\left(210 \mu \mathrm{g} \mathrm{m}^{-3}\right)$ was found at DAK because it is located near open burning. However, the average concentration at CMU $\left(74.5 \pm 43.5 \mu \mathrm{g} . \mathrm{m}^{-3}\right)$ was higher than that at DAK $\left(59.1 \pm 44.1 \mu \mathrm{g} \cdot \mathrm{m}^{-3}\right)$, which was obviously affected by precipitation in early March. Rain amount measured at Chiang Mai $(17 \mathrm{~mm})$ was much lower than that at DAK $(115 \mathrm{~mm})$. It therefore reduced PM2.5 concentrations by the wash out effect. However, after the rain period, open burning started again and PM2.5 become higher. Most of PM2.5 concentrations from both sampling sites exceeded the Thailand National Ambient Air Quality Standard (NAAQS) $\left(50 \mu \mathrm{g} \cdot \mathrm{m}^{-3}\right)$. Higher wind speed may increase airborne particulate distribution, while calm wind supports air pollutant accumulation. Average wind speed at $\operatorname{DAK}(10 \mathrm{~m} / \mathrm{s})$ was higher than at CMU $(5.2 \mathrm{~m} / \mathrm{s})$. Another important factor is mixing height (the height to which the lower atmosphere will undergo mechanical or turbulent 
mixing, producing a nearly homogeneous air mass) [11]. The average mixing height of Chiang Mai Province in March is about $1465 \mathrm{~m}$ above sea level. DAK site $(1534 \mathrm{~m})$ is located above the mixing height, whereas CMU site $(373 \mathrm{~m})$ is located under the mixing height level. This is an important reason that PM2.5 concentrations were higher at CMU site than those at DAK. Below mixing height the air was quite steady and air pressure was high, resulting in pollutant accumulation at lower atmosphere. However, the PM2.5 concentrations obtained from different sites and instruments were analyzed to find out the correlation of each pair. PM2.5 concentrations of CMU and DAK were well correlated ( $r=$ $0.780)$ and no significant difference $(p>0.05)$ was found. These high concentrations were well agreed with the hotspot number (1683) detected in Chiang Mai Province in March 2013 [12]. Moreover, the trend of daily PM2.5 concentrations obtained from both techniques was similar (Fig. 2). Correlation of PM2.5 concentrations obtained from a mini-volume air sampler and TEOM were strong both at CMU $(r=0.957)$ and DAK $(r=0.723)$ (Table II).

TABLE I: AVERAGE CONCENTRATIONS $\left(\mu \mathrm{G}^{-3}{ }^{-3}\right)$ OF PM2.5, RAIN PRECIPITATION AND WIND SPEED IN DRY SEASON 2013

\begin{tabular}{lccccccccc}
\hline \multirow{2}{*}{ Stations } & \multicolumn{3}{c}{ Dry season (March 13) } & \multicolumn{3}{c}{ Total Precipitation } & \multicolumn{2}{c}{ Wind Speed (m/s) } \\
\cline { 2 - 9 } & $\mathrm{N}$ & Average \pm SD & Min & Max & Amount (mm) & Days & Average & Min & Max \\
\hline Doi Ang Khang (DAK) & 29 & $59.1 \pm 44.1^{\mathrm{a}}$ & 2.7 & 210 & 115 & 6 & 10.0 & 5.2 & 21.6 \\
Chiang Mai University (CMU) & 31 & $74.5 \pm 43.5^{\mathrm{a}}$ & 9.3 & 159 & 17 & 4 & 5.2 & 2.6 & 9.8 \\
\hline \hline
\end{tabular}

${ }^{a}$ non-significant difference $(p>0.05)$ from t-test.

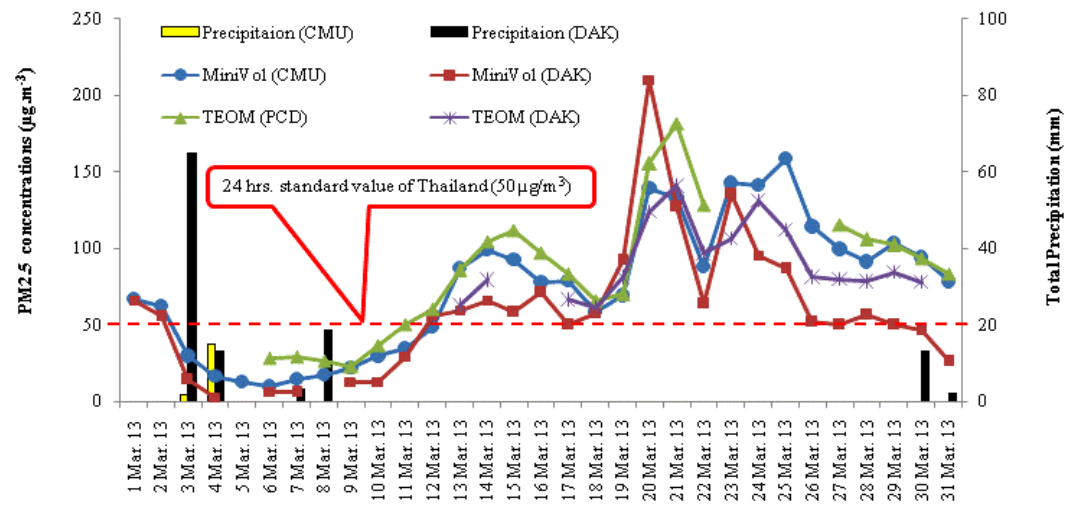

Fig. 2. Daily PM2.5 concentrations $\left(\mu \mathrm{g} \mathrm{m}^{-3}\right)$ at DAK and CMU sites obtained from gravimetric method comparing with TEOM.

TABLE II: THE CORRELATION OF PM2.5 CONCENTRATION OBTAINED FROM A Mini-VOLUME Air SAMPLER AND TEOM

\begin{tabular}{lccc}
\hline \hline & MiniVol (CMU) & MiniVol (DAK) & TEOM (DAK) \\
\hline MiniVol (CMU) & 1 & & 1 \\
MiniVol (DAK) & 0.780 & 0.820 & 1 \\
TEOM (DAK) & 0.778 & 0.774 & 0.805 \\
TEOM (PCD) & 0.957 & 1 & 1 \\
\hline \hline
\end{tabular}

TABLE III: AVERAGE CONCENTRATIONS $\left(\mu \mathrm{G} . \mathrm{M}^{-3}\right)$ OF PM2.5-BOUND ELEMENTS COLLECTED FROM DAK AND CMU SITES

\begin{tabular}{|c|c|c|c|c|c|c|c|c|c|c|c|c|c|c|}
\hline Site & & $\mathrm{Al}$ & $\mathrm{Cd}$ & $\mathrm{Cr}$ & $\mathrm{Cu}$ & $\mathrm{Fe}$ & $\mathrm{K}$ & $\mathrm{Mg}$ & $\mathrm{Mn}$ & $\mathrm{Ni}$ & $\mathrm{Pb}$ & $\mathrm{Sb}$ & $\mathrm{V}$ & Total \\
\hline \multirow[t]{2}{*}{ DAK } & Mean & 0.851 & 0.006 & 0.100 & 0.011 & 0.396 & 2.060 & 0.842 & 0.011 & 0.034 & 0.041 & 0.039 & 0.037 & 4.428 \\
\hline & SD & 0.214 & 0.002 & 0.082 & 0.004 & 0.306 & 0.711 & 0.582 & 0.007 & 0.027 & 0.031 & 0.026 & 0.021 & 2.012 \\
\hline \multirow[t]{2}{*}{ CMU } & Mean & 0.695 & 0.007 & 0.055 & 0.005 & 0.161 & 2.231 & 0.938 & 0.010 & 0.024 & 0.038 & 0.044 & 0.140 & 4.349 \\
\hline & SD & 0.305 & 0.003 & 0.018 & 0.005 & 0.098 & 0.703 & 0.849 & 0.005 & 0.013 & 0.028 & 0.027 & 0.017 & 2.070 \\
\hline
\end{tabular}

\section{B. Air Mass Movement}

Average 24 hours backward trajectories to DAK and CMU in March 2013 were performed to classify air mass movements (Fig. 3). The data $(n=31)$ in each site was grouped into 4 clusters. The main direction of air mass movement to DAK originated from the Myanmar continental area and directly moved east before arriving at the receptor (cluster $1 ; 45 \%$ ) and the PM2.5 concentrations ranged from $50-75 \mu \mathrm{g} \cdot \mathrm{m}^{-3}$ (41\%) (Fig. 4). About $26 \%$ of trajectories were from the southwest direction near the border between Thailand and Myanmar, while $23 \%$ were locally originated. The main direction of the air mass trajectory (52\%) at CMU site came from the southwest direction, where large areas of crop and rice fields are located together with forest area. The PM2.5 concentrations from the southwest direction ranged from $75-100 \mu \mathrm{g} \cdot \mathrm{m}^{-3}$ (32\%) (Fig. 4). Approximately $19 \%$ was from the western direction in a short distance (local origin).

\section{Concentrations of PM2.5-Bound Elements}

Elemental concentrations of the PM2.5 samples for the two sampling sites are shown in Table III. The average concentrations $\left(\mu \mathrm{g} \cdot \mathrm{m}^{-3}\right)$ of dominant elements from DAK samples in descending order were $\mathrm{K}>\mathrm{Al}>\mathrm{Mg}>\mathrm{Fe}$, while those from $\mathrm{CMU}$ were $\mathrm{K}>\mathrm{Mg}>\mathrm{Al}>\mathrm{Fe}$. The other elements such as $\mathrm{Cd}, \mathrm{Cu}, \mathrm{Ni}, \mathrm{Pb}$ and $\mathrm{Sb}$ were found to be lower than the 
instrument detection limit values. The major elements found in this study ( $\mathrm{Al}, \mathrm{Mg}$ and $\mathrm{Fe}$ ) were the same with other studies [13] performed in Chiang Mai. Ambient air elemental composition was often related with Earth's crustal elements (Al, Fe, Mg and $\mathrm{Mn}$ ) [14]. Al represents crustal elements of earth origin, while $\mathrm{Fe}$ is a major component in soil which may be contributed by wind [15]. This study found that $\mathrm{K}$ was a major element in PM2.5, which was well agreed with previous studies performed in Chiang Mai [16] and in Korea [2]. The correlations between PM2.5 and K concentrations from DAK and CMU were 0.814 and 0.641 , respectively. Relatively high correlation at DAK site supported the fact that the site is located near sources of biomass burning.

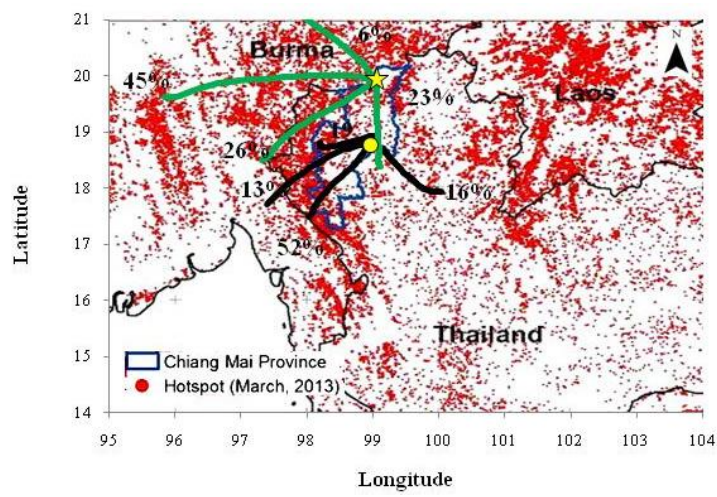

Fig. 3. Average 24-h back trajectory for the main trajectory cluster at DAK and CMU and hotspots number in March.

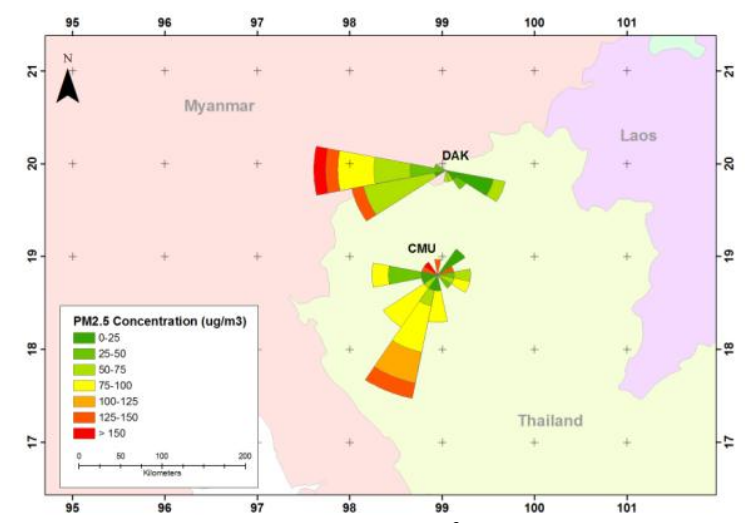

Fig. 4. PM2.5 concentration $\left(\mu \mathrm{g} . \mathrm{m}^{-3}\right)$ with wind direction.

\section{CONCLUSION}

The average PM2.5 concentration at the receptor site was higher than that at the near source sampling site. The main factors were the geographical location and meteorological conditions, including mixing height level. Potassium (biotracer of biomass burning) was found to be a major element bound with PM2.5 collected from both sites. It can be concluded that PM2.5 was emitted from biomass burning such as open burning of agricultural waste and forest fire. The PM2.5 concentrations at the near source site could be higher than at the receptor when intensive open burning is performed. However, the average concentrations can vary based on aforementioned factors.

\section{ACKNOWLEDGMENTS}

The financial support from the Graduate School of Chiang Mai University and the National Research University (NRU) are gratefully acknowledged.

\section{REFERENCES}

[1] S. Y. Ryu, B. G. Kwon, Y. J. Kim, H. H. Kim, and K. J. Chun, "Characteristics of biomass burning aerosol and its impact on regional air quality in the summer of 2003 at Gwangju, Korea," Atmospheric Research, vol. 84, pp. 362-373, 2007.

[2] D. M. Goto, M. Lanc, C. A. Obuti, C. M. Galvão Barbosa, P. H Nascimento Saldiva, D. M. Trevisan Zanetta, G. Lorenzi-Filho, and U. de Paula Santos, "Effects of biomass burning on nasal mucociliary clearance and mucus properties after sugarcane harvesting," Environmental Research, vol. 111, pp. 664-669, 2011.

[3] N. T. K. Oanh, T. L. Bich, D. Tipayaroma, B. R. Manandhar, P. Prapat, C. D. Simpson, and L. J. Sally Liu, "Characterization of particulate matter emission from open burning of rice straw," Atmospheric Environment, vol. 45, pp. 493-502, 2011

[4] N. T. K. Oanh and K. Leelasakultum, "Analysis of meteorology and emission in haze episode prevalence over mountain-bounded region for early warning," Science of the Total Environmental, vol. 409, pp. 2261-2271, 2011.

[5] Pollution Control Department, Maryland Department of the Environment and Chiangmai Municipality, "Chiangmai emission inventory in municipality and neighbourhood area," Report of Ability of Federal and Local Government Official, Chiangmai, 2002.

[6] D. W. Dockery and P. H. Stone, "Cardiovascular risks from fine particulate air pollution," New England Journal of Medicine, vol. 356 , pp. 511-513, 2007.

[7] K. R. Anderson, E. L. Avol, S. A. Edwards, D. A. Shamoo, R. C. Peng, W. S. Linn, and J. D. Hackney, "Controlled exposure of volunteers to respirable carbon and sulfuric acid aerosols," Journal of the Air \& Waste Management Association, vol. 42, pp. 770-776, 1992.

[8] N. H. Lin, S. C. Tsay, H. B. Maring, M. C. Yen, G. R. Sheu, S. H Wang, K. H. Chi, "An overview of regional experiments on biomass burning aerosols and related pollutants in Southeast Asia: From BASE-ASIA and the Dongsha Experiment to 7-SEAS," Atmospheric Environment, vol. 78, pp. 1-19, 2013.

[9] The Air Resources Laboratory (ARL). [Online]. Available: https://ready.arl.noaa.gov/HYSPLIT.php), 1/07/14

[10] Q. Wang, C. Zhu, Y. Wang, Z. Huang, Z. Li, B. Huang, K. Tsunoda, and K. Satake, "A novel sampling method for present and historical monitoring of air pollution by using tree bark," Environmental Chemisry, vol. 22, no. 3, pp. 250-254, 2003.

[11] National Oceanic and Atmospheric Administration. (2014). [Online]. Available: http://graphical.weather.gov/definitions/defineMixHgt.html

[12] EOSDIS. (2013). [Online]. Available: https://earthdata.nasa.gov/data/near-real-time-data/firms

[13] S. Chantara, S. Wangkarn, U. Tengjaroenkul, W. Sangchang, and M. Rayanakorn, "Chemical analysis of airborne particulates for air pollutants in Chiang Mai and Lumphun Provinces, Thailand," Chiang Mai Journal of Science, vol.36, pp. 123-135, 2009.

[14] S. A. Paulino, J. V. Cirilo, S. L. Quiterio, G. Arbilla, and V. Escaleira, "Analysis of the impact of emission from the petrochemical complex in the campos eliseos on the air quality of air basin IIU," Brazilian Journal of Petroleum and Gas, vol. 3, no. 2, pp. 67-64, 2009.

[15] N. Tippayawong, P. Pengchai, and A. Lee, "Characterization of ambient aerosols in northern Thailand and their probable sources," International Journal of Environmental Science and Technology, vol 3, no. 4, pp. 359-369, 2006.

[16] U. Vinitketkumnuen, K. Kalayanamitra, T. Chewonaria, and R. Kamens, "Particulate matter, PM10 \& PM2.5 levels and airborne mutagenicity in Chiang Mai, Thailand," Mutation Research, vol. 519, pp. 121-131, 2002.

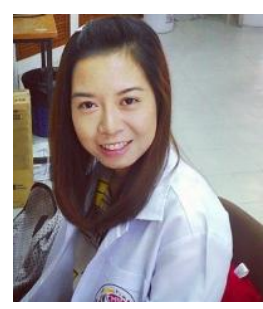

Chanakarn Khamkaew was born in Chiang Rai Province, Thailand in 1983. Her educational background was a bachelor degree from the biology program at Narasuan University (NU), Thailand in 2006. Her master degree is from the environmenta science program at Chiang Mai University (CMU), Thailand in 2010. Now, She is a Ph.D. student of the environmental science program at CMU and a member of the Environmental Chemistry Research Laboratory (ECRL). Her research contributions are in the field of environmental analytical chemistry. She has been in the air quality monitoring and assessment of air pollutants source including sampling and 
analysis of nitrogen dioxide $\left(\mathrm{NO}_{2}\right)$, metals and ion-bound PM2.5 in ambient air. She is interested in hybrid single particle lagrangian integrated trajectory model (HYSPLIT).

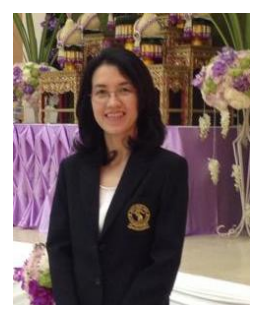

Somporn Chantara was born in Tak province, Thailand in 1970. She earned a bachelor degree in chemistry from Chiang Mai University, Thailand in 1992. Her master degree was a double degree in environmental risk assessment for tropical ecosystems (international program) from Chiang Mai University (CMU), Thailand and University of Saarland, Germany in 1994. Her last degree was Dr. rer. Nat. (biogeographie) from Trier University, Germany in 2000. Now, She is a lecturer in the Chemistry Department, Faculty of Science, Chiang Mai University. Her most significant research contributions are in the field of environmental analytical chemistry, air quality monitoring and assessment of air pollutants sources including sampling and analysis of atmospheric acid deposition, development of passive samplers for determination of air pollutants.

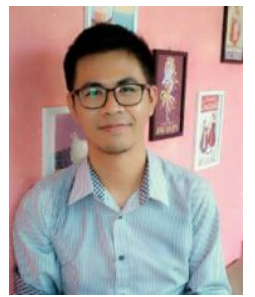

Wan Wiriya was born in Chiang Mai province, Thailand in 1981. His educational background was a bachelor degree in biochemistry and biochemistry technology from Chiang Mai University (CMU), Thailand in 2004. He graduated with the M.Sc. degree and Ph.D. degree in environmental science program from CMU, Thailand in 2008 and 2013, respectively. Now, he is a lecturer in the Chemistry Department, Faculty of Science, Chiang Mai University. His research contributions are in the field of environmental anlytical chemistry. He has been in the air quality monitoring and assessment of air pollutants sources including sampling and analysis of atmospheric acid deposition and PAHs-bound PM10. He is interested in air pollution models such as DRs, PCA, PMF and HYSPILT model. 